\title{
Is area-level socioeconomic deprivation associated with mortality due to circulatory system diseases in Poland?
}

Jacek Jamiołkowski ( $\sim$ jacek.jamiolkowski@umb.edu.pl )

Medical University of Białystok https://orcid.org/0000-0001-8442-9944

Agnieszka Genowska

Medical University of Białystok

Andrzej Pająk

Jagiellonian University Medical College

\section{Research Article}

Keywords: cardiovascular disease, deprivation, smoking, body mass index, urbanization, health inequalities

Posted Date: August 23rd, 2022

DOI: https://doi.org/10.21203/rs.3.rs-135518/v2

License: () (i) This work is licensed under a Creative Commons Attribution 4.0 International License. Read Full License 


\section{Abstract \\ Background.}

Socioeconomic deprivation (SED) is known to influence cardiovascular health. However, studies analyzing the relationship between deprivation and circulatory system diseases (CSD) in Central and Eastern Europe are limited. This study aimed to assess the relationship between SED and mortality due to CSD at a population level in 66 sub-regions of Poland.

\section{Methods.}

The data regarding mortality and SED components were obtained from the Central Statistical Office. An area-based SED index was estimated from the rates of education, structure in employment, salary, unemployment, as well as and poverty. The dynamics of changes in mortality due to CSD was calculated as the number of deaths prevented or postponed (DPP) in terciles of SED index. The associations between the mortality from CSD and SED index were analyzed using multivariate Poisson regression models and generalized estimating equations.

\section{Results.}

Among men, the percentage of DPP in 2014 was $13.1 \%$ for CSD, $23.4 \%$ for ischemic heart disease (IHD), and $21.4 \%$ for cerebrovascular diseases (CD). In the case of women, the proportion of DPP was $12.8 \%, 25.6 \%$, and $21.6 \%$, respectively. More deprived sub-regions experienced a greater decrease in CSD-related mortality compared to the less deprived sub-regions. The disparity in mortality reduction between more deprived and less deprived sub-regions was even more pronounced for women. After adjustment for lifestyle, population density, and changes in mortality over time, the SED index was found to be associated with CSD- and IHD-related mortality for men $(\beta=1.053,95 \%$ confidence interval (CI) 1.008-1.100 and $\beta=1.195$, $95 \% \mathrm{Cl} 1.005-1.419$, respectively), and with IHD- and CD-related mortality for women $(\beta=1.303,95 \% \mathrm{Cl} 1.025-1.657$ and $\beta$ $=1.230,95 \% \mathrm{Cl} 1.025-1.477$, respectively).

\section{Conclusions.}

A major proportion of the territorial differences in mortality due to CSD in Poland could be attributed to socioeconomic deprivation. To reduce CSD mortality, more comprehensive preventive measures, including approaches addressing the socioeconomic factors, mainly poverty, education and employment, in particular in less urbanized areas are needed.

\section{Background}

Circulatory system diseases (CSD), which originate from atherosclerotic disease and include both the ischemic heart disease (IHD) and cerebrovascular diseases (CD), have been reported for many years the most common causes of death in the developed countries. In nonfatal cases, long-term treatment is required, which limits an individual's capacity to work and consequently incurs a high cost in terms of both treatment and loss of professional productivity, particularly in those over 50 years of age $[1,2]$.

The burden of CSD is unequally distributed across Europe, with a higher mortality in the central and eastern regions $[3,4]$. This higher burden reported in post-communist countries has been somewhat inherited due to several historical reasons associated with socioeconomic system of that time. Central and Eastern European countries are characterized by a lower gross domestic product per capita, and thereby, a lower expenditure on health care, and also a limited access to health care services and prevention. Furthermore, the health care gap between the Eastern and Western populations may result from, or could be explained by, lifestyle and differences in socioeconomic influences [5]. The difference in the mortality due to CSD is 
dependent on socioeconomic position (SEP), which is determined mainly by education, type of occupation, and income. This indicates the need to include SEP along with the classical factors in the risk assessment of CSD [6, 7]. Low SEP may contribute to stress-related biological risk factors associated with the development of cardiovascular diseases (hypertension, proinflammatory cytokines, diabetes, obesity) [8]. Furthermore, it may lead to poorer health as a result of harmful health behaviors, such as tobacco smoking, unhealthy diet, and lower physical activity $[9,10]$. In addition to individual factors, CSDrelated mortality could be linked with socioeconomic deprivation (SED) at the area level [11-15]. Deprivation is a state of observable and demonstrable disadvantages, which can be of social or material nature, in comparison to the local community or the wider society to which an individual, family, or group belongs [16]. The area-related deprivation serves as a proxy for the SEP of the people who live in those regions, and characterizes the living environment which can influence an individual's prospects for education, profession, income, or access to resources, and hence, health outcomes $[7,17]$. Furthermore, neighborhood factors could have an impact on health through a lack of investments or inequality in resource redistribution in society. Moreover, chronic exposure to psychosocial stress, caused by poverty areas, is linked to the development of multisystemic adverse biological changes, i.e., allostatic burden, which results in cardiovascular diseases [18]. Studies indicate that factors associated with area SED could significantly affect short-term survival, while individual factors may have a considerable impact on long-term survival [12].

The majority of information on the relationship between SED and cardiovascular disease-related mortality comes from the studies conducted in Western Europe and the United States [13-15, 19,20], while much fewer data are available from the Central and Eastern European countries [21, 22]. Recent studies conducted in Poland, Russia, and Czech Republic have confirmed a strong association between the risk of death from CSD and psycho-socioeconomic factors [23, 24]. However, there is a need for a more extensive assessment of the factors determining health inequalities among people in the Central European countries, including Poland. The political transformation that occurred in 1989 in Poland led to significant changes in social structures $[25,26]$. Despite the considerable increase of SEP, certain professional groups adapted to the new market economy at a slower rate, which resulted in increased social and health inequalities. Furthermore, economic changes decreased employment in the heavy industry and national farm holdings [27, 28], leading to economic and social inequalities in the area of residence, i.e., impoverishment and social exclusion, and consequently excessive alcohol consumption due to changes in availability and affordability $[25,29]$. Thus far, analyses have mostly focused on changes in CSD mortality caused by changes in the exposure to traditional risk factors (cholesterol, blood pressure), changes in lifestyle, and improvement of health care services $[30,31]$. No study has investigated the socioeconomic factors at the population level. It is likely that territorial variations in CSD mortality in Poland may be explained by SED differences and their changes over time.

This study aimed to assess the relationship between SED and mortality due to CSD at a population level in 66 sub-regions of Poland.

\section{Methods}

An ecological study was performed using the data on SED, lifestyle, urbanization, and mortality due to CSD collected from 66 administrative sub-regions of Poland. The sub-regions were defined according to the Nomenclature des Unités Territoriales Statistiques (NUTS-3) in 2006 [32]. The mean size of the sub-regions was 4,738 $\mathrm{km}^{2}$, with a wide range of variation between eight urban-type sub-regions (from 262 to $517 \mathrm{~km}^{2}$ ) and 58 remaining sub-regions (from 878 to $12,090 \mathrm{~km}^{2}$ ). Average number of population per sub-region (in year 2010) was 583,786, and ranged from 279,491 to $1,700,112$. Descriptive statistics for the sub-regions were weighted for the number of sub-region population using weights as follows:

$$
W_{X}=\frac{\text { population }_{X} \cdot n}{\text { population }_{\text {total }}}
$$

where: 
population $_{x}$ is the population of sub-region $\mathrm{x}$,

population $_{\text {total }}$ is the total population of Poland, and

$n$ is the number of sub-regions.

The sum of weights for all sub-regions is equal to the number of sub-regions.

The data for the period 2010-2014 were obtained from the Central Statistical Office and the Social Diagnosis Survey which has been conducted every 2 years since 2000 on the same sample of households [33].

Mortality

Data on deaths during 2010-2014 were used for the analysis of mortality. According to the International Statistical Classification of Diseases and Related Health Problems, Tenth Revision (ICD-10), the causes for the deaths were encoded as CSD (codes: I00-199), including IHD (I20-I25) and CD (160-169).

The age-standardized number of deaths was used for statistical analyses. A direct standardization method was utilized for the analyses, considering the demographic structure in 5-year age groups (from 15-19 years to 80-84 years, and above 84 years old) separately for each of the 66 sub-regions of Poland [34]. European Standard Population - 2013 edition was assumed as standard population, and standardized mortality coefficients were determined accordingly [35]. The coefficients of standardized mortality were calculated as $95 \%$ confidence intervals (Cls).

The dynamics of changes in mortality rates in the period 2010-2014 was assessed by calculating the deaths prevented or postponed (DPP) index [36]. The index value was expressed in percentage and estimated as the difference between the expected number of deaths in 2014, assuming that the mortality rate in 2014 was the same as in 2010, and the actual number of deaths in 2014 relative to the expected number of deaths in 2014:

$$
D P P=\frac{\text { deathsexpected }_{2014}-\text { deathsobserved }_{2014}}{\text { deathsexpected }_{2014}} \cdot 100 \%
$$

Area-level SED index

Five SED indicators were selected from the available variables in the system of routine statistical records from the Central Statistical Office. The selected indicators of SED were as follows: people with higher education, people employed in industry and construction, average monthly salary, unemployment rate, and people on social support due to poverty. These variables were chosen as they showed a strong correlation with all-cause mortality [37]. According to published literature data, the SED variables are potential predictors of the geographical distribution of CSD mortality [38-43]. Education not only increases the awareness of beneficial health behaviors, through medical and prophylactic care as well as treatment recommendations, but is also one of the important determinants of employment $[38,39]$. The professional class, which is characterized by a balance between effort and reward, is associated with health. Similarly, people employed in industry and construction are manual workers and exhibit worse health outcomes [40]. Income determines an individual's access to better-quality goods and services and housing to stay healthy [41]. Thus, unemployment is linked with disease development, due to reduced access to medical care and screening programs resulting from the lack of health insurance [42]. Poverty associated with a lack of social support leads to chronic stress and adverse health behaviors $[18,43]$. To calculate the SED index, its component variables were standardized via linear transformation such that the expected value of the variables was equal to 0 and the standard deviation was equal to 1. In addition, for destimulants (proportion of people with higher education and average monthly salary), their sign was reversed. Finally, the SED index was assumed as the arithmetic mean of the transformed components and calculated from the averaged values of component variables for the period 2010-2014. Therefore, proposed SED index might be considered as mean of Z-Scores of its components, taking into account inverted scales for destimulant variables. The calculated index values were used to explain the differences in mortality across sub-

Page 4/21 
regions of Poland. In addition, based on the values of the SED index, the 66 sub-regions were divided into three tercile groups: the group with the lowest index values and thus the lowest deprivation level (less deprived); the group with the highest index values (more deprived); and the middle group. This classification was used to emphasize the inequalities in mortality for descriptive purposes.

Other explanatory variables

Tobacco consumption and body mass index (BMI) were calculated for the 66 sub-regions based on the results of the Social Diagnosis Survey conducted in 2011. The survey involved 12,386 households which were selected based on the two-stage stratified sampling method-first at the voivodeship level, followed by sampling based on residential location (large cities, small cities, and villages) [33]. The study sample comprised 36,753 persons, aged 16 years and over. The participation rate of the study was $72 \%$ (i.e., 26,453 persons were examined finally). To eliminate the socioeconomic differences in urbanization between the sub-regions in the model, population density was included as a standardizing factor $[19,44]$.

\section{Statistical analysis}

The relationship between mortality and the SED index was determined using the multivariate Poisson regression model for count data. As this model reflected the mortality coefficient per 100,000 residents, rather than the number of deaths, the agestandardized number of deaths in individual sub-regions was taken as a dependent variable, with the number of people in sub-regions serving as the offset. The generalized linear models with Poisson distribution as probability distribution and logarithm as a link function were used for calculations.

Due to repeated measurements in the same statistical units (mortality in sub-regions in subsequent years during 20102014), generalized estimating equations (GEE) were used for obtaining generalized linear models for the correlated data [45]. In GEE models, an exchangeable structure was assumed for the working correlation matrix.

The Poisson models were presented with exponentially transformed regression coefficients. Therefore, they can be interpreted as the expected relative change of dependent variable (number of deaths standardized for the age) calculated for a one-unit increase of independent variable, i.e., relative risk. The reported coefficients can also be interpreted as a relative change in mortality coefficients, and not just death numbers. Furthermore, $95 \%$ Cls were calculated for the coefficients of the regression model and their $p$-values of corresponding Wald's tests.

The regression models developed for the study included three causes of death (CSD, IHD, CD) for men and women. As independent variables, calendar year (for assessing the time effect on the dependent variable) and the aforementioned index -level of socioeconomic deprivation in the sub-regions-were included in the models. In addition, the models included lifestyle factors, such as BMI and frequency of smoking tobacco in the sub-region (for the female and male population, respectively) and population density in the sub-region using logistic transformation at base 2.

Statistical calculations were performed in the IBM ${ }^{\circledR}$ SPSS $®$ Statistics for Windows statistical package, version 20.0 (IBM Corporation, Armonk, NY, USA). The level of statistical significance was assumed at $a=0.05$.

\section{Results}

During 2010-2014, a total of 868,418 deaths due to CSD were recorded in Poland, which included 405,235 deaths among men $(46.7 \%)$. Of the overall death number, the deaths due to CSD in men accounted for $40.6 \%$, while the death proportion in women reached $51.2 \%$. Among CSD, IHD (32.0\%) and CD (24.6\%) were determined as the main causes of deaths.

The descriptive statistics for socioeconomic variables, lifestyle, and urbanization, by three sub-groups of Polish sub-regions (classified based on the SED index values), are presented in Table 1. The mean values of the index variables in sub-groups reflect their role as stimulants or destimulants-in the sub-regions characterized by the highest SED index (a more deprived), 
high values were attained by stimulants and low values by destimulants. Therefore, this group of sub-regions had the highest percentage of unemployment rate (18.4\%), percentage of people who are on social support due to poverty (11.1\%) and people employed in industry and construction (31.1.\%), as well as the lowest percentage of people with university education (12.9\%) and people with average monthly salary (3,108 PLN). Opposite characteristics occurred in the sub-regions with the lowest SED index values (less deprived), which had the lowest unemployment rate (8.9\%) and the lowest percentage people on social support due to poverty (5.3\%). On the other hand, these sub-regions had the highest percentage of people with university education (22.5\%) and highest average monthly salary (3,916 PLN). The precise distributions of SED components are shown on the maps presented in Supplemental Fig. 1. 
Table 1

Descriptive statistics for SED, lifestyle characteristics, and urbanization in 66 sub-regions of Poland during the period 2010-2014 by categories of SED index weighted for the size of sub-region population

\begin{tabular}{|c|c|c|c|}
\hline Index of socioeconomic deprivation (tercile) & $\begin{array}{l}\text { 1st tercile } \\
\text { (less deprived }\end{array}$ & $\begin{array}{l}\text { 2nd tercile } \\
\text { (middle) }\end{array}$ & $\begin{array}{l}\text { 3rd tercile } \\
\text { (more deprived) }\end{array}$ \\
\hline SED index range & -2.66 to -0.07 & -0.07 to 0.33 & 0.34 to 1.15 \\
\hline \multicolumn{4}{|l|}{ SED INDEX and its components } \\
\hline \multirow[t]{2}{*}{ SED index } & $-0.92 \pm 0.82$ & $0.17 \pm 0.10$ & $0.63 \pm 0.28$ \\
\hline & $(-1.64 /-0.58 /-0.27)$ & $(0.10 / 0.18 / 0.26)$ & $(0.42 / 0.50 / 0.88)$ \\
\hline \multirow[t]{2}{*}{ University education [\%] } & $22.48 \pm 7.66$ & $13.62 \pm 1.75$ & $12.92 \pm 1.68$ \\
\hline & $(17.14 / 20.36 / 28.49)$ & $(12.60 / 13.38 / 14.12)$ & $(12.00 / 12.69 / 14.07)$ \\
\hline \multirow[t]{2}{*}{ Employed in industry and construction [\%] } & $27.54 \pm 9.41$ & $27.30 \pm 10.04$ & $31.05 \pm 5.33$ \\
\hline & $(20.54 / 25.24 / 34.72)$ & $(18.47 / 27.16 / 35.20)$ & $(27.57 / 33.20 / 34.83)$ \\
\hline \multirow[t]{2}{*}{ Average salary [PLN] } & $3,916 \pm 550$ & $3,173 \pm 207$ & $3,108 \pm 156$ \\
\hline & $(3,463 / 3,852 / 4,260)$ & $(3,048 / 3,135 / 3,237)$ & $(2,972 / 3,113 / 3,227)$ \\
\hline \multirow[t]{2}{*}{ Unemployment rate [\%] } & $8.93 \pm 3.34$ & $13.90 \pm 2.33$ & $18.37 \pm 3.66$ \\
\hline & $(5.54 / 9.49 / 11.26)$ & $(13.14 / 14.33 / 15.17)$ & $(16.09 / 18.56 / 20.49)$ \\
\hline \multirow[t]{2}{*}{ People on social support due to poverty [\%] } & $5.30 \pm 1.70$ & $9.10 \pm 2.16$ & $11.10 \pm 2.25$ \\
\hline & $(3.44 / 5.33 / 6.35)$ & $(7.24 / 9.44 / 10.56)$ & $(8.85 / 11.62 / 13.33)$ \\
\hline \multicolumn{4}{|l|}{ Lifestyle indicators } \\
\hline \multirow[t]{2}{*}{ Smoking (men) [\%] } & $32.3 \pm 4.4$ & $31.5 \pm 4.9$ & $35.8 \pm 6.3$ \\
\hline & $(28.6 / 32.9 / 35.3)$ & $(28.4 / 30.8 / 34.1)$ & $(31.5 / 35.9 / 41.8)$ \\
\hline \multirow[t]{2}{*}{ Smoking (women) [\%] } & $22.4 \pm 4.4$ & $16.9 \pm 4.1$ & $20.9 \pm 5.1$ \\
\hline & $(20.5 / 22.8 / 26.2)$ & $(14.4 / 16.2 / 19.4)$ & $(18.4 / 20.4 / 25.5)$ \\
\hline \multirow[t]{2}{*}{$\mathrm{BMI}$ (men) $\left[\mathrm{kg} / \mathrm{m}^{2}\right]$} & $26.4 \pm 0.4$ & $26.4 \pm 0.3$ & $26.6 \pm 0.4$ \\
\hline & $(26.0 / 26.3 / 26.8)$ & $(26.2 / 26.3 / 26.5)$ & $(26.4 / 26.6 / 26.8)$ \\
\hline \multirow[t]{2}{*}{ BMI (women) $\left[\mathrm{kg} / \mathrm{m}^{2}\right]$} & $25.0 \pm 0.4$ & $25.4 \pm 0.3$ & $25.4 \pm 0.4$ \\
\hline & $(24.6 / 25.1 / 25.3)$ & $(25.1 / 25.3 / 25.6)$ & $(25.1 / 25.4 / 25.6)$ \\
\hline \multicolumn{4}{|l|}{ Urbanization } \\
\hline \multirow[t]{2}{*}{ Population density [n/km²] } & $1,124.8 \pm 1,167.4$ & $127.3 \pm 79.7$ & $89.5 \pm 30.4$ \\
\hline & $(171.4 / 395.6 / 2,141.9)$ & $(78.0 / 97.7 / 163.2)$ & $(62.3 / 88.6 / 106.0)$ \\
\hline \multicolumn{4}{|c|}{ Values are presented as mean \pm standard deviation (first quartile/median/third quartile) } \\
\hline \multicolumn{4}{|c|}{ Abbreviation: SED-socioeconomic deprivation; BMI-body mass index } \\
\hline
\end{tabular}

Substantial difference in population density was noted between the three groups of sub-regions. In the more deprived subregions, it was on average 89 people/ $\mathrm{km}^{2}$, while in the less deprived sub-regions it was over 13-fold higher-1,125 people/ $\mathrm{km}^{2}$, which indicates that low SED index values are mainly linked with highly urbanized areas. The percentage of 
smoking men was similar in all the three groups of sub-regions, ranging from 32.3-35.8\%, and in women from 20.9-22.4\%, whereas a higher proportion of smoking men was found in the tercile representing those more deprived in comparison with those less deprived, and an inverse outcome was observed in women. No significant differences were found for nutritional behaviors. The mean BMI of male and female populations was in the range of $26.4-26.6$ and $25.0-25.4 \mathrm{~kg} / \mathrm{m}^{2}$, respectively.

The territorial distribution of sub-regions by SED index is presented in Fig. 1. The less deprived sub-regions with the lowest SED index value primarily had large urban agglomerations.

Mortality due to CSD was the highest in the more deprived sub-regions and the middle group, and the lowest in those with the less deprived. Simultaneously, the dynamics of mortality increased in the period 2010-2014, which was reflected by a significant decrease in the percentage of DPP with an increase in the SED index value $(p<0.001)$. In the case of men, the IHD-related mortality was the lowest in the more deprived sub-regions. In addition, an increase in the percentage of DPP was observed in these sub-regions $(p<0.001)$. The relationship between the deaths due to CD in men and the SED index was unambiguous. The highest CD-related mortality was observed in the sub-regions that were characterized by an average level of socioeconomic deprivation. However, a statistically significant linear increase in the percentage of DPP was observed in these sub-regions $(p<0.01)$ (Table 2). 
Table 2

Age-standardized mortality rates from CSD and proportion of DPP in men in the years 2010 and 2014 by index of SED tercile groups.

\begin{tabular}{|c|c|c|c|c|c|c|c|c|}
\hline \multirow{2}{*}{$\begin{array}{l}\text { Index of } \\
\text { SED } \\
\text { Calendar } \\
\text { year }\end{array}$} & \multicolumn{2}{|c|}{$\begin{array}{l}\text { 1st tercile (less } \\
\text { deprived) }\end{array}$} & \multicolumn{2}{|c|}{ 2nd tercile (middle) } & \multicolumn{2}{|c|}{$\begin{array}{l}\text { 3rd tercile (more } \\
\text { deprived) }\end{array}$} & \multicolumn{2}{|l|}{ Total } \\
\hline & 2010 & 2014 & 2010 & 2014 & 2010 & 2014 & 2010 & 2014 \\
\hline $\begin{array}{l}\text { Population } \\
\text { number }\end{array}$ & $\begin{array}{l}N= \\
6,177,556\end{array}$ & $\begin{array}{l}N= \\
6,176,172\end{array}$ & $\begin{array}{l}N= \\
4,981,098\end{array}$ & $\begin{array}{l}N= \\
4,993,735\end{array}$ & $\begin{array}{l}N= \\
4,491,158\end{array}$ & $\begin{array}{l}N= \\
4,491,604\end{array}$ & $\begin{array}{l}N= \\
15,649,812\end{array}$ & $\begin{array}{l}N= \\
15,661,511\end{array}$ \\
\hline \multicolumn{9}{|c|}{ Circulatory system diseases } \\
\hline $\begin{array}{l}\text { SMR }(95 \% \\
\mathrm{Cl})\end{array}$ & $\begin{array}{l}867.80 \\
(857.68- \\
877.93)\end{array}$ & $\begin{array}{l}768.16 \\
(759.44- \\
776.89)\end{array}$ & $\begin{array}{l}1000.08 \\
(987.59- \\
1012.56)\end{array}$ & $\begin{array}{l}867.96 \\
(857.03- \\
878.89)\end{array}$ & $\begin{array}{l}1003.10 \\
(989.06- \\
1017.13)\end{array}$ & $\begin{array}{l}858.13 \\
(846.06- \\
870.21)\end{array}$ & $\begin{array}{l}944.81 \\
(937.93- \\
951.69)\end{array}$ & $\begin{array}{l}822.42 \\
(816.47- \\
828.36)\end{array}$ \\
\hline $\begin{array}{l}\text { Observed } \\
\text { number of } \\
\text { deaths }\end{array}$ & 31,614 & 31,321 & 27,128 & 25,655 & 22,705 & 21,827 & 81,447 & 78,803 \\
\hline $\begin{array}{l}\text { Expected } \\
\text { number of } \\
\text { deaths* }\end{array}$ & & 35,434 & & 29,839 & & 25,291 & & 90,649 \\
\hline $\begin{array}{l}\text { Number } \\
\text { (percentage) } \\
\text { of DPP } \\
\text { relative to } \\
\text { expected } \\
\text { deaths }\end{array}$ & & $\begin{array}{l}4,113 \\
(11.6 \%)\end{array}$ & & $\begin{array}{l}4,184 \\
(14.0 \%)\end{array}$ & & $\begin{array}{l}3,464 \\
(13.7 \%)\end{array}$ & & $\begin{array}{l}11,846 \\
(13.1 \%)\end{array}$ \\
\hline $\begin{array}{l}\text { Linear trend } \\
\text { for DPP }\end{array}$ & $p<0.001$ & & & & & & & \\
\hline \multicolumn{9}{|c|}{ Ischemic heart disease } \\
\hline $\begin{array}{l}\text { SMR }(95 \% \\
\mathrm{Cl})\end{array}$ & $\begin{array}{l}266.91 \\
(261.32- \\
272.50)\end{array}$ & $\begin{array}{l}217.49 \\
(212.84- \\
222.14)\end{array}$ & $\begin{array}{l}288.34 \\
(281.65- \\
295.03)\end{array}$ & $\begin{array}{l}208.50 \\
(203.21- \\
213.80)\end{array}$ & $\begin{array}{l}259.22 \\
(252.13- \\
266.30)\end{array}$ & $\begin{array}{l}185.19 \\
(179.65- \\
190.72)\end{array}$ & $\begin{array}{l}271.68 \\
(268.01- \\
275.35)\end{array}$ & $\begin{array}{l}206.44 \\
(203.48- \\
209.40)\end{array}$ \\
\hline $\begin{array}{l}\text { Observed } \\
\text { number of } \\
\text { deaths }\end{array}$ & 10,240 & 9,206 & 8,291 & 6,695 & 6,342 & 5,142 & 24,873 & 21,043 \\
\hline $\begin{array}{l}\text { Expected } \\
\text { number of } \\
\text { deaths* }\end{array}$ & & 11,353 & & 9,067 & & 7,029 & & 27,468 \\
\hline $\begin{array}{l}\text { Number } \\
\text { (percentage) } \\
\text { of DPP } \\
\text { relative to } \\
\text { expected } \\
\text { deaths }\end{array}$ & & $\begin{array}{l}2,147 \\
(18.9 \%)\end{array}$ & & $\begin{array}{l}2,372 \\
(26.2 \%)\end{array}$ & & $\begin{array}{l}1,887 \\
(26.8 \%)\end{array}$ & & $\begin{array}{l}6,425 \\
(23.4 \%)\end{array}$ \\
\hline $\begin{array}{l}\text { Linear trend } \\
\text { for DPP }\end{array}$ & $p<0.001$ & & & & & & & \\
\hline rebrovasc & diseases & & & & & & & \\
\hline
\end{tabular}

Abbreviations: CSD -circulatory system diseases; DPP-deaths prevented or postponed; SED-socioeconomic deprivation; SMR-standardized mortality rate per 100,000 population; $\mathrm{Cl}$-confidence interval;

*Assuming that death rates by age groups from 2010 persist in 2014 


\begin{tabular}{|c|c|c|c|c|c|c|c|c|}
\hline \multirow{2}{*}{$\begin{array}{l}\begin{array}{l}\text { Index of } \\
\text { SED }\end{array} \\
\text { SMR (95\% } \\
\text { CI) }\end{array}$} & \multicolumn{2}{|c|}{$\begin{array}{l}\text { 1st tercile (less } \\
\text { deprived) }\end{array}$} & \multicolumn{2}{|c|}{ 2nd tercile (middle) } & \multicolumn{2}{|c|}{$\begin{array}{l}\text { 3rd tercile (more } \\
\text { deprived) }\end{array}$} & \multicolumn{2}{|l|}{ Total } \\
\hline & $\begin{array}{l}156.82 \\
(152.45- \\
16119)\end{array}$ & $\begin{array}{l}123.73 \\
(120.20- \\
127.26)\end{array}$ & $\begin{array}{l}199.50 \\
(193.86- \\
205.15)\end{array}$ & $\begin{array}{l}156.16 \\
(151.45- \\
160.86)\end{array}$ & $\begin{array}{l}173.50 \\
(167.60- \\
179.41)\end{array}$ & $\begin{array}{l}136.00 \\
(131.12- \\
140.89)\end{array}$ & $\begin{array}{l}174.77 \\
(171.77- \\
177.76)\end{array}$ & $\begin{array}{l}136.96 \\
(134.50- \\
139.42)\end{array}$ \\
\hline $\begin{array}{l}\text { Observed } \\
\text { number of } \\
\text { deaths }\end{array}$ & 5,722 & 5,143 & 5,149 & 4,383 & 4,457 & 3,834 & 15,328 & 13,360 \\
\hline $\begin{array}{l}\text { Expected } \\
\text { number of } \\
\text { deaths* }\end{array}$ & & 6,389 & & 5,697 & & 4,896 & & 16,991 \\
\hline $\begin{array}{l}\text { Number } \\
\text { (percentage) } \\
\text { of DPP } \\
\text { relative to } \\
\text { expected } \\
\text { deaths }\end{array}$ & & $\begin{array}{l}1,246 \\
(19.5 \%)\end{array}$ & & $\begin{array}{l}1,314 \\
(23.1 \%)\end{array}$ & & $\begin{array}{l}1,062 \\
(21.7 \%)\end{array}$ & & $\begin{array}{l}3,631 \\
(21.4 \%)\end{array}$ \\
\hline $\begin{array}{l}\text { Linear trend } \\
\text { for DPP }\end{array}$ & $p<0.01$ & & & & & & & \\
\hline \multicolumn{9}{|c|}{$\begin{array}{l}\text { Abbreviations: CSD - circulatory system diseases; DPP-deaths prevented or postponed; SED-socioeconomic } \\
\text { deprivation; SMR-standardized mortality rate per 100,000 population; Cl-confidence interval; }\end{array}$} \\
\hline
\end{tabular}

The relationship between the SED index and CSD-related mortality in women was similar to that in men. The agestandardized CSD mortality was the lowest in the sub-regions with the lowest deprivation, while the highest one occurred in the middle group sub-regions. The percentage of prevented deaths increased significantly with the increase of the SED index value $(p<0.001)$. Similarly, mortality due to IHD was the lowest in the more deprived sub-regions and the highest (in 2014) in the less deprived sub-regions. The percentage of DPP increased significantly $(p<0.001)$ with an increase in the SED index value. Similar to men, mortality due to $\mathrm{CD}$ in women was the highest in middle sub-regions and the lowest in less deprived sub-regions. No significant differences were observed in the percentage of prevented deaths $(p=0.11)$, and the differences were found at the same level in all the three groups of sub-regions studied (Table 3). 
Table 3

Age-standardized mortality rates from CSD and proportion of DPP in women in the years 2010 and 2014 by index of SED tercile groups.

\begin{tabular}{|c|c|c|c|c|c|c|c|c|}
\hline \multirow{2}{*}{$\begin{array}{l}\text { Index of } \\
\text { SED } \\
\text { Calendar } \\
\text { year }\end{array}$} & \multicolumn{2}{|c|}{$\begin{array}{l}\text { 1st tercile (less } \\
\text { deprived) }\end{array}$} & \multicolumn{2}{|c|}{ 2nd tercile (middle) } & \multicolumn{2}{|c|}{$\begin{array}{l}\text { 3rd tercile (more } \\
\text { deprived) }\end{array}$} & \multicolumn{2}{|l|}{ Total } \\
\hline & 2010 & 2014 & 2010 & 2014 & 2010 & 2014 & 2010 & 2014 \\
\hline $\begin{array}{l}\text { Population } \\
\text { number }\end{array}$ & $\begin{array}{l}N= \\
6,960,632\end{array}$ & $\begin{array}{l}N= \\
6,972,552\end{array}$ & $\begin{array}{l}N= \\
5,285,442\end{array}$ & $\begin{array}{l}N= \\
5,303,620\end{array}$ & $\begin{array}{l}N= \\
4,778,214\end{array}$ & $\begin{array}{l}N= \\
4,776,768\end{array}$ & $\begin{array}{l}N= \\
17,024,288\end{array}$ & $\begin{array}{l}N= \\
17,052,940\end{array}$ \\
\hline \multicolumn{9}{|c|}{ Circulatory system diseases } \\
\hline $\begin{array}{l}\text { SMR }(95 \% \\
\text { Cl) }\end{array}$ & $\begin{array}{l}583.09 \\
(577.17- \\
589.02)\end{array}$ & $\begin{array}{l}525.64 \\
(520.35- \\
530.92)\end{array}$ & $\begin{array}{l}675.01 \\
(667.70- \\
682.31)\end{array}$ & $\begin{array}{l}581.20 \\
(574.79- \\
587.62)\end{array}$ & $\begin{array}{l}652.36 \\
(644.44- \\
660.27)\end{array}$ & $\begin{array}{l}550.03 \\
(543.18- \\
556.87)\end{array}$ & $\begin{array}{l}630.58 \\
(626.59- \\
634.57)\end{array}$ & $\begin{array}{l}549.65 \\
(546.14- \\
553.15)\end{array}$ \\
\hline $\begin{array}{l}\text { Observed } \\
\text { number of } \\
\text { deaths }\end{array}$ & 35,893 & 36,652 & 31,330 & 30,194 & 25,255 & 24,060 & 92,478 & 90,906 \\
\hline $\begin{array}{l}\text { Expected } \\
\text { number of } \\
\text { deaths* }\end{array}$ & & 39,876 & & 33,396 & & 30,998 & & 104,307 \\
\hline $\begin{array}{l}\text { Number } \\
\text { (percentage) } \\
\text { of DPP } \\
\text { relative to } \\
\text { expected } \\
\text { deaths }\end{array}$ & & $\begin{array}{l}3,483 \\
(8.7 \%)\end{array}$ & & $\begin{array}{l}5,228 \\
(15.7 \%)\end{array}$ & & $\begin{array}{l}4,653 \\
(15.0 \%)\end{array}$ & & $\begin{array}{l}13,401 \\
(12.8 \%)\end{array}$ \\
\hline $\begin{array}{l}\text { Linear trend } \\
\text { for DPP }\end{array}$ & $p<0.001$ & & & & & & & \\
\hline \multicolumn{9}{|c|}{ Ischemic heart disease } \\
\hline \multirow[t]{2}{*}{$\begin{array}{l}\text { SMR }(95 \% \\
\text { Cl) }\end{array}$} & $\begin{array}{l}140.78 \\
(137.80- \\
143.75)\end{array}$ & $\begin{array}{l}114.80 \\
(112.28- \\
117.32)\end{array}$ & $\begin{array}{l}154.05 \\
(150.46- \\
157.63)\end{array}$ & $\begin{array}{l}106.72 \\
(103.89- \\
109.55)\end{array}$ & $\begin{array}{l}131.79 \\
(128.14- \\
135.44)\end{array}$ & $\begin{array}{l}90.60 \\
(87.76-\end{array}$ & $\begin{array}{l}142.63 \\
(140.69- \\
144.57)\end{array}$ & $\begin{array}{l}105.88 \\
(104.30- \\
107.46)\end{array}$ \\
\hline & & & & & & $93.44)$ & & \\
\hline $\begin{array}{l}\text { Observed } \\
\text { number of } \\
\text { deaths }\end{array}$ & 8,693 & 7,998 & 7,167 & 5,521 & 5,099 & 3,975 & 20,959 & 17,494 \\
\hline $\begin{array}{l}\text { Expected } \\
\text { number of } \\
\text { deaths* }\end{array}$ & & 9,802 & & 7,974 & & 5,734 & & 23,523 \\
\hline $\begin{array}{l}\text { Number } \\
\text { (percentage) } \\
\text { of DPP } \\
\text { relative to } \\
\text { expected } \\
\text { deaths }\end{array}$ & & $\begin{array}{l}1,804 \\
(18.4 \%)\end{array}$ & & $\begin{array}{l}2,453 \\
(30.8 \%)\end{array}$ & & $\begin{array}{l}1,759 \\
(30.7 \%)\end{array}$ & & $\begin{array}{l}6,029 \\
(25.6 \%)\end{array}$ \\
\hline $\begin{array}{l}\text { Linear trend } \\
\text { for DPP }\end{array}$ & $p<0.001$ & & & & & & & \\
\hline
\end{tabular}

Abbreviations: CSD - circulatory system diseases; DPP-deaths prevented or postponed; SED-socioeconomic deprivation; SMR-standardized mortality rate per 100,000 population; $\mathrm{Cl}$-confidence interval;

*Assuming that death rates by age groups from 2010 persist in 2014 


\begin{tabular}{|c|c|c|c|c|c|c|c|c|}
\hline \multirow{3}{*}{$\begin{array}{l}\text { Index of } \\
\text { SED } \\
\text { SMR (95\% } \\
\text { Cl) }\end{array}$} & \multicolumn{2}{|c|}{$\begin{array}{l}\text { 1st tercile (less } \\
\text { deprived) }\end{array}$} & \multicolumn{2}{|c|}{ 2nd tercile (middle) } & \multicolumn{2}{|c|}{$\begin{array}{l}\text { 3rd tercile (more } \\
\text { deprived) }\end{array}$} & \multicolumn{2}{|l|}{ Total } \\
\hline & \multirow{3}{*}{$\begin{array}{l}126.60 \\
(123.79- \\
129.42)\end{array}$} & 98.83 & \multirow{3}{*}{$\begin{array}{l}155.87 \\
(152.27- \\
159.46)\end{array}$} & \multirow{3}{*}{$\begin{array}{l}121.97 \\
(118.94- \\
124.99)\end{array}$} & \multirow{3}{*}{$\begin{array}{l}128.49 \\
(124.91- \\
132,07)\end{array}$} & 102.09 & \multirow{3}{*}{$\begin{array}{l}136.39 \\
(134.50- \\
138.28)\end{array}$} & \multirow{3}{*}{$\begin{array}{l}106.94 \\
(105.36 \\
108.53)\end{array}$} \\
\hline & & (96.48- & & & & (99.07- & & \\
\hline & & 101.17) & & & & 105.11) & & \\
\hline $\begin{array}{l}\text { Observed } \\
\text { number of } \\
\text { deaths }\end{array}$ & 7,861 & 6,875 & 7,307 & 6,310 & 5,063 & 4,458 & 20,231 & 17,643 \\
\hline $\begin{array}{l}\text { Expected } \\
\text { number of } \\
\text { deaths* }\end{array}$ & & 8,806 & & 8,049 & & 5,627 & & 22,500 \\
\hline $\begin{array}{l}\text { Number } \\
\text { (percentage) } \\
\text { of DPP } \\
\text { relative to } \\
\text { expected } \\
\text { deaths }\end{array}$ & & $\begin{array}{l}1,931 \\
(21.9 \%)\end{array}$ & & $\begin{array}{l}1,739 \\
(21.6 \%)\end{array}$ & & $\begin{array}{l}1,169 \\
(20.8 \%)\end{array}$ & & $\begin{array}{l}4,857 \\
(21.6 \%)\end{array}$ \\
\hline $\begin{array}{l}\text { Linear trend } \\
\text { for DPP }\end{array}$ & $p=0.11$ & & & & & & & \\
\hline \multicolumn{9}{|c|}{$\begin{array}{l}\text { Abbreviations: CSD - circulatory system diseases; DPP-deaths prevented or postponed; SED-socioeconomic } \\
\text { deprivation; SMR-standardized mortality rate per 100,000 population; } \mathrm{Cl}-\text { confidence interval; }\end{array}$} \\
\hline
\end{tabular}

The classification of sub-groups into three tercile groups was adapted to simplify description and generalization of conclusions. A more detailed analysis of the five quintile groups of SED index values can be found in Supplemental Tables 1 and 2.

The relationship between CSD mortality and time, SED, lifestyle, and population density is presented in Table 4. For both women and men, a statistically significant decrease was observed for mortality due to CSD $(2.9 \%$ for men and $2.8 \%$ for women annually), IHD (6.6\% for men and 7.7\% for women annually), and CD (6.1\% for men and 6.6\% for women annually). Similarly, a relationship between SED and increased mortality was found for deaths due to CSD and IHD in men and deaths due to IHD and CD in women. A higher mean BMI was associated with higher mortality due to CSD among women, but no significant relationship was observed between BMI and mortality due to IHD and CD. In the case of men, a relationship was noted between smoking and mortality due to CSD. Low SED index (by and large related to urban agglomerations) was found to be related to lower mortality, while a high population density was associated with greater IHD mortality in women and men and CD mortality only in women. 
Relation between mortality from CSD and SED index (linear effect), lifestyle, and population density in 66 sub-regions of Poland, 2010-2014

\begin{tabular}{|c|c|c|c|c|c|}
\hline \multirow[t]{2}{*}{ Group diseases } & \multirow[t]{2}{*}{ Variables in the model } & \multicolumn{2}{|l|}{ Men } & \multicolumn{2}{|l|}{ Women } \\
\hline & & $\begin{array}{l}\exp (\beta) \text { with } 95 \% \\
\mathrm{Cl}\end{array}$ & $p$ & $\begin{array}{l}\exp (\beta) \text { with } 95 \% \\
\mathrm{Cl}\end{array}$ & $p$ \\
\hline \multirow{5}{*}{$\begin{array}{l}\text { Circulatory system } \\
\text { diseases } \\
\text { (ICD-10: 100-199) }\end{array}$} & Time [1-year increase] & $\begin{array}{l}0.971(0.967 \\
0.976)\end{array}$ & 0.000 & $\begin{array}{l}0.972(0.966 \\
0.978)\end{array}$ & 0.000 \\
\hline & SED index [1-unit increase] & $\begin{array}{l}1.053(1.008, \\
1.100)\end{array}$ & 0.020 & $\begin{array}{l}1.047(0.992, \\
1.106)\end{array}$ & 0.092 \\
\hline & BMI [1-kg/m² increase] & $\begin{array}{l}1.018(0.956 \\
1.084)\end{array}$ & 0.584 & $\begin{array}{l}1.076(1.009 \\
1.148)\end{array}$ & 0.026 \\
\hline & Smoking [1\% increase] & $\begin{array}{l}1.005(1.002 \\
1.009)\end{array}$ & 0.004 & $\begin{array}{l}0.996(0.991 \\
1.001)\end{array}$ & 0.111 \\
\hline & $\begin{array}{l}\text { Population density [twofold } \\
\text { increase] }\end{array}$ & $\begin{array}{l}0.995(0.972 \\
1.017)\end{array}$ & 0.639 & $\begin{array}{l}1.004(0.978 \\
1.030)\end{array}$ & 0.776 \\
\hline \multirow{5}{*}{$\begin{array}{l}\text { Ischemic heart disease } \\
\text { (ICD-10: I20-I25) }\end{array}$} & Time [1-year increase] & $\begin{array}{l}0.934(0.914 \\
0.955)\end{array}$ & 0.000 & $\begin{array}{l}0.923(0.891 \\
0.956)\end{array}$ & 0.000 \\
\hline & SED index [1-unit increase] & $\begin{array}{l}1.195(1.005 \\
1.419)\end{array}$ & 0.043 & $\begin{array}{l}1.303(1.025 \\
1.657)\end{array}$ & 0.031 \\
\hline & BMI [1-kg/m² increase] & $\begin{array}{l}1.079(0.895 \\
1.300)\end{array}$ & 0.426 & $\begin{array}{l}0.994(0.764 \\
1.293)\end{array}$ & 0.963 \\
\hline & Smoking [1\% increase] & $\begin{array}{l}1.003(0.990 \\
1.015)\end{array}$ & 0.698 & $\begin{array}{l}0.994(0.977 \\
1.012)\end{array}$ & 0.520 \\
\hline & $\begin{array}{l}\text { Population density [twofold } \\
\text { increase] }\end{array}$ & $\begin{array}{l}1.094(1.006, \\
1.189)\end{array}$ & 0.036 & $\begin{array}{l}1.145(1.018, \\
1.288)\end{array}$ & 0.024 \\
\hline \multirow{5}{*}{$\begin{array}{l}\text { Cerebrovascular } \\
\text { diseases } \\
\text { (ICD-10: 160-169) }\end{array}$} & Time [1-year increase] & $\begin{array}{l}0.939(0.930 \\
0.949)\end{array}$ & 0.000 & $\begin{array}{l}0.934(0.914 \\
0.955)\end{array}$ & 0.000 \\
\hline & SED index [1-unit increase] & $\begin{array}{l}1.008(0.921 \\
1.102)\end{array}$ & 0.869 & $\begin{array}{l}1.230(1.025, \\
1.477)\end{array}$ & 0.026 \\
\hline & BMI [1-kg/m² increase] & $\begin{array}{l}1.090(0.979 \\
1.213)\end{array}$ & 0.117 & $\begin{array}{l}0.983(0.809 \\
1.194)\end{array}$ & 0.862 \\
\hline & Smoking [ $1 \%$ increase] & $\begin{array}{l}1.006(0.998 \\
1.014)\end{array}$ & 0.113 & $\begin{array}{l}0.993(0.977 \\
1.008)\end{array}$ & 0.342 \\
\hline & $\begin{array}{l}\text { Population density [twofold } \\
\text { increase] }\end{array}$ & $\begin{array}{l}0.967(0.918 \\
1.019)\end{array}$ & 0.208 & $\begin{array}{l}1.107(1.012 \\
1.211)\end{array}$ & 0.027 \\
\hline \multicolumn{6}{|c|}{ CSD -circulatory system diseases; SED-socioeconomic deprivation } \\
\hline \multicolumn{6}{|c|}{$\begin{array}{l}\text { Separate models for each disease group by gender including the effects of time trend, SED index, BMI, prevalence of } \\
\text { smoking, and population density }\end{array}$} \\
\hline \multicolumn{6}{|c|}{ Significant results are shown in bold } \\
\hline
\end{tabular}

\section{Discussion}

Main findings 
The study showed a large geographic variation in the CSD mortality and SED in the 66 sub-regions of Poland. For both men and women, the largest mortality was found in the more deprived and middle group sub-regions, and the lowest in the less deprived sub-regions. However, in the more deprived and middle group sub-regions benefited more from the decrease in CSD mortality in men and women. In women, the differences in the number of DPP between the SED groups were similar to that in men, except in the case of CD for which a nonsignificant trend was observed. The relationship between SED and CSD mortality was found to be significant in men after adjusting for mean BMI, mean smoking rate, and population density. In women, a significant relationship was observed with mean BMI, but the relationship between CSD mortality and SED was not significant after adjusting for covariates, although the $\beta$ coefficients were similar to that of men.

Interpretation of results

Our study indicates that the variation of CSD mortality in the sub-regions of Poland can be explained at least partially by the differences in SED. The results comply with those of the studies in which synthetic SED indexes were used to assess the relationship between deprivation and mortality due to CSD and IHD [13-15, 19-22]. It has been suggested that deprivation significantly influences the mortality due to CSD in men compared to women $[13,46]$. Gender differences in mortality can be possibly associated with profession due to elevated exposure to risk factors, particularly among male manual workers [47]. Furthermore, this study confirmed the relationship between SED and mortality from IHD and CD in women, which was also highlighted in other studies [48-50].

In our study, CSD mortality was shown to be associated with tobacco smoking only in men. This could reflect the higher smoking rates in the group of more deprived sub-regions as compared with the less deprived sub-regions. According to the MORGAM study, in Poland, smoking is less prevalent among women characterized by low and secondary education as compared with women with higher education, particularly in less urbanized areas [51]. A study indicated that in Eastern European countries, economic development and social as well as cultural processes associated with gender empowerment affect the differences in smoking between educated and uneducated women [52].

Our results showed inequalities in mortality across sub-regions ranked by deprivation. The lowest CSD mortality was observed in the less deprived sub-regions, which predominantly include large urban agglomerations and small cities. This may be associated with the fact that these sub-regions have access to different resources, including educational infrastructure, services, and job opportunities [50]. Furthermore, these sub-regions offer a more favorable environment, such as access to gyms and shops selling healthy foods, as well as health care services, which may contribute to better health outcomes in their residents $[44,53,54]$. The more deprived sub-regions are located in the eastern and northwest parts of Poland and are characterized by a low population density. These are considered less attractive to investors, which affects economic development. This confirms, among others, the fact that the areas of many sub-regions with a more deprived subregions overlap with those areas in which national farm holdings had been liquidated and more harmful effects of the economic transformation are experienced. These areas lack support programs targeting social groups deprived of earlier forms of employment, and hence are consequently linked with poor health outcomes [26, 27]. Furthermore, the area encompassing sub-regions with a high deprivation in the western part of the country was associated with a more explicit trend toward job migrations to work legally abroad. The migrations may exacerbate a optimal development of these areas due to outflow of human capital, and are also associated with a prevalence of social exclusion and poverty, leading altogether to health hazards $[26,55]$.

However, a reverse trend was observed for IHD-related mortality-the mortality was the highest in the less deprived sub-region group. In the case of CD, the highest mortality was found in middle sub-regions, which may suggest the occurrence of other specific factors that are not included in the study (e.g., differences in access to medical care on stroke units) [56]. It should also be emphasized that a rapid decrease in CSD mortality was noted in more deprived sub-regions with high SED index values. In the more deprived and middle group sub-regions, the percent of DPP was higher as compared with the less deprived sub-regions. 
While the mortality due to CSD and CD was the lowest in the less deprived sub-regions, the reduction of mortality between 2010 and 2014 was smaller in these sub-regions compared to the sub-regions with the high SED index. This could be explained by the fact that in the best-developed-highly urbanized-sub-regions, mortality (due to better availability of cardiologic care services and invasive cardiology procedures) had been reduced in earlier years and the scope for improvement of cardiovascular health was narrower [57]. Simultaneously, in more deprived and middle sub-regions, modern prevention and therapeutic methods are increasingly becoming accessible. For example, life-saving invasive cardiology procedures have been available after 2000 not only in academic centers but also in district hospitals, which might have resulted in reduced mortality even in smaller centers with a higher SED index. This is also supported by the results of other analyses [57], according to which the reduction of mortality due to CSD among people with higher education was particularly pronounced between 1991-1993 and 2001-2003, whereas during the period 2001-2003 and 2010-2012, the reduction was considerably lower. Noticeably, this reduction of mortality was observed at a lower rate in people with low education in comparison to those with higher education.

The stratification using terciles allowed to identify the residence-related deprivation which may be of importance at intervention strategies and activities addressing improvement of cardiovascular health. In the policy process aimed to alleviate health inequalities, the activities should focus not only on the poverty reduction throughout income redistribution. It is also critical ensuring equality of health opportunity in the entire population, through education, employment, improve working conditions and preventive care [58]. Decreasing health inequalities ought to be a political and social priority, given they deteriorate economic productivity and the potential of sustainable and inclusive growth.

Strengths and limitations

To our knowledge, this study is the first to use the SED index to assess the relationship with mortality due to CSD at the population level in Poland. The study was performed considering the whole population of the country. In the 66 sub-regions, a large variation was found in CSD mortality and SED. Furthermore, the sub-regions represented all the characteristics that are typical for Poland. The synthetic SED index enabled an approximate estimation of the singular variables (education, structure in employment, salary, unemployment, and poverty). A database concerning sub-regions defined based on NUTS-3 classification, which is used in the European Union member states, was used for the first time in this study [32]. A unique strength of this study was the comparison of mortality due to CSD and the time-related changes using the DPP index in three different environments regarding deprivation level, thus, contrary to other studies reporting mortality trends in administrative areas of the country [57]. Our results showed a potent effect of health inequalities and may be, therefore, a contribution to limited literature field dealing with the associations between area-related deprivation and mortality from CSD in Central and Eastern European countries [21, 22]. Similar and comparable socioeconomic levels in specific countries of this region may facilitate cross-comparisons and may allow consistently conduct research across the populations.

The results of the study should be interpreted in light of certain limitations. The ecological design does not allow addressing the causality of the relationships. As sub-regions were considered as statistical units in this study, instead of individual persons, it was possible to investigate the inequalities between the sub-regions, while inequalities within them remain unexplored. Epidemiological analyses for geographical areas lead to best results when statistical units are populations of small size $[59,60]$. It allows for better homogeneity and decreases the problem of averaging of different populations within single geographical area. Such averaging results in attenuation of studied effects in statistical models. In this paper population sizes in sub-regions were relatively large, so it was expectable that real effects might be significantly stronger and so their detection could be difficult, if not impossible. However, we were able to confirm statistically significant relationships of SED index with 4 out of 6 analyzed mortality indicators. In contrast to mortality and SED, information on covariates such as education, smoking, and BMI was based on one-point observation (Census 2011, Social Diagnosis Survey 2011), which was only available for the studied sub-regions and corresponded with the study period. It is unlikely that these characteristics changed much within the observation time. The relationship between SED and mortality due to CSD could be confounded by the sub-region differences in the exposure to the other uncontrolled factors; therefore, residual confounding should be taken into account. For example, we did not utilize stress as an important variable because of limited accessibility or missing data.

Page 15/21 
However, stress is regarded a significant mediator linking the associations between deprivation and mortality due to cardiovascular diseases [61]. Noticeably, some components of the SED (e.g. percent of people on social support due to poverty) may have, at least partly, reflect the chronic stress [18]. Thus, the role of stress should be investigated in future research. Another limitation of the study is the quality of the data on deaths associated with the differences in the reliability of death-cause coding by physicians who filled out death certificates. Our results showed that the highest mortality due to IHD was observed in the less deprived (most urbanized) sub-regions. This may be explained partially by the discrepancies in death certification encoding which has been described earlier in Poland [62]. Such issue was even reported in countries with highly advanced health information systems [63]. However, territorial differences in death-cause coding could rather contribute to the greater impact of random variability on our results, and it is less likely that the occurrence of a systematic error would explain the observed relationships. The latter is supported by the overall accordance of relationships found for $\mathrm{IHD}, \mathrm{CD}$, and CSD.

\section{Conclusions}

SED explains a major portion of the territorial differences in mortality due to CSD in Poland. To reduce CSD mortality, more comprehensive preventive measures, including approaches addressing the socioeconomic factors, mainly poverty, education and employment, are needed in particular in less urbanized areas. Further well-designed studies should take into account a contribution of psychosocial factors and their effect on cardiovascular health.

\section{Abbreviations}

BMI: body mass index; CD: cerebrovascular diseases; Cl: confidence interval; CSD: circulatory system diseases; DPP: deaths prevented or postponed; GEE: generalized estimating equations; ICD: International Statistical Classification of Diseases and Related Health Problems; IHD: ischemic heart disease; NUTS: Nomenclature des Unités Territoriales Statistiques; SED: socioeconomic deprivation; SEP: socioeconomic position.

\section{Declarations}

Ethics approval and consent to participate: not required.

The data used in this study are aggregated secondary data that hasn't any personal identifying information that can be linked to study participants. Therefore no ethics approval was required for this study.

Consent for publication: not applicable.

\section{Availability of data and materials}

The datasets analyzed during the current studies are publicly available in Central Statistical Office, Poland (https://stat.gov.pl).

\section{Competing interest}

The authors declare that they have no competing interests.

\section{Funding:}

The study was financed by the Polish National Science Centre (grant number 2016/23/D/HS4/01887). Author who received the funding: AG. The funders had no role in study design, data collection and analysis, decision to publish, or preparation of the manuscript.

\section{Authors' Contributions}

Page 16/21 
Conceptualization: JJ, AG, AP; Data curation: AG; Formal Analysis: JJ; Funding Acquisition: AG; Investigation: AG, JJ; Methodology: JJ, AG; Project administration: AG; Software: JJ; Supervision: AG, AP; Validation: AG; Writing - original draft preparation: JJ, AG, AP; Writing - review and supervision: AP. All authors read and approved the final manuscript.

Acknowledgements: not applicable.

\section{References}

1. Gańczak M, Miazgowski T, Kożybska M, Kotwas A, Korzeń M, Rudnicki B, et al. Changes in disease burden in Poland between 1990-2017 in comparison with other Central European countries: A systematic analysis for the Global Burden of Disease Study 2017. PLoS One. 2020;15(3):e0226766. https://doi.org/10.1371/journal.pone.0226766.

2. Genowska A, Fryc J, Pinkas J, Jamiołkowski J, Szafraniec K, Szpak A, et al. Social costs of loss in productivity-related absenteeism in Poland. Int J Occup Med Environ Health. 2017;30(6):917-932.

https://doi.org/10.13075/ijomeh.1896.01123.

3. Naghavi M, Abajobir AA, Abbafati C, Abbas KM, Abd-Allah F, Abera SF, et al. Global, regional, and national age-sex specific mortality for 264 causes of death, 1980-2016: a systematic analysis for the Global Burden of Disease Study 2016. Lancet. 2017;390(10100):1151-1210. https://doi.org/10.1016/S0140-6736(17)32152-9.

4. Nichols M, Townsend N, Scarborough P, Rayner M. Trends in age-specific coronary heart disease mortality in the European Union over three decades: 1980-2009. Eur Heart J. 2013;34(39):3017-3027.

https://doi.org/10.1093/eurheartj/eht159.

5. Hartley A, Marshall DC, Salciccioli JD, Sikkel MB, Maruthappu M, Shalhoub J. Trends in Mortality From Ischemic Heart Disease and Cerebrovascular Disease in Europe: 1980 to 2009. Circulation.2016;133(20):1916-1926. https://doi.org.10.1161/CIRCULATIONAHA.115.018931.

6. Kaplan GA, Keil JE. Socioeconomic factors and cardiovascular disease: a review of the literature. Circulation 1993;88(Pt 1):1973-1998. https://doi.org/10.1161/01.cir.88.4.1973.

7. Galobardes B, Shaw M, Lawlor DA, Lynch JW, Davey Smith G. Indicators of socioeconomic position (part 2). J Epidemiol Community Health. 2006;60(2):95-101. https://doi.org/10.1136/jech.2004.028092.

8. Steptoe A, Hiltl TJ, Dowd JB, Hamer M. Socioeconomic status and central adiposity as determinants of stress-related biological responses relevant to cardiovascular disease risk. Brain Behav Immun. 2019;77:16-24.

https://doi.org/10.1016/j.bbi.2018.11.019.

9. Zujko ME, Waśkiewicz A, Drygas W, Cicha-Mikołajczyk A, Zujko K, Szcześniewska D, et al. Dietary habits and dietary antioxidant intake are related to socioeconomic status in Polish adults: a nationwide study. Nutrients. 2020;12(2). pii: E518. https://doi.org/10.3390/nu12020518.

10. Algren MH, Ekholm O, Nielsen L, Ersbøll AK, Bak CK, Andersen PT. Associations between perceived stress, socioeconomic status, and health-risk behaviour in deprived neighbourhoods in Denmark: a cross-sectional study. BMC Public Health. 2018;18(1):250. https://doi.org/10.1186/s12889-018-5170-x.

11. Diez Roux AV, Merkin SS, Arnett D, Chambless L, Massing M, Nieto FJ, et al. Neighborhood of residence and incidence of coronary heart disease. N Engl J Med 2001;345(2):99-106. https://doi.org/doi:10.1056/NEJM200107123450205.

12. Coady SA, Johnson NJ, Hakes JK, Sorlie PD. Individual education, area income, and mortality and recurrence of myocardial infarction in a Medicare cohort: the National Longitudinal Mortality Study. BMC Public Health. 2014;14:705. https://doi.org/10.1186/1471-2458-14-705.

13. Machón M, Aldasoro E, Martínez-Camblor P, Calvo M, Basterretxea M, Audicana C, et al. Socioeconomic differences in incidence and relative survival after a first acute myocardial infarction in the Basque Country, Spain. Gac Sanit. 2012;26(1):16-23. https://doi.org/10.1016/j.gaceta.2011.06.013.

14. Ramsay SE, Morris RW, Whincup PH, Subramanian SV, Papacosta AO, Lennon LT, et al. The influence of neighbourhoodlevel socioeconomic deprivation on cardiovascular disease mortality in older age: longitudinal multilevel analyses from 
a cohort of older British men. J Epidemiol Community Health. 2015;69(12):1224-1231. https://doi.org/ 10.1136/jech2015-205542.

15. Moissl AP, Delgado GE, Krämer BK, März W, Kleber ME, Grammer TB. Area-based socioeconomic status and mortality: the Ludwigshafen Risk and Cardiovascular Health study. Clin Res Cardiol. 2020;109(1):103-114. https://doi.org/10.1007/s00392-019-01494-y.

16. Townsend P. Deprivation. J Soc Policy. 1987;16:125-146. https://doi.org/10.1017/S0047279400020341.

17. Pampalon R, Raymond G. A deprivation index for health and welfare planning in Quebec. Chronic Dis Canada. 2000;21(3):104-113.

18. Robinette JW, Charles ST, Almeida DM, Gruenewald TL. Neighborhood features and physiological risk: an examination of allostatic load. Health Place. 2016;41:110-118. https://doi.org/10.1016/j.healthplace.2016.08.003.

19. Rey G, Jougla E, Fouillet A, Hémon D. Ecological association between a deprivation index and mortality in France over the period 1997 - 2001: variations with spatial scale, degree of urbanicity, age, gender and cause of death. BMC Public Health. 2009;9:33. doi: 10.1186/1471-2458-9-33. https://doi.org/10.1186/1471-2458-9-33.

20. Singh GK, Siahpush M, Azuine RE, Williams SD. Increasing area deprivation and socioeconomic inequalities in heart disease, stroke, and cardiovascular disease mortality among working age populations, United States, 1969-2011. Int J MCH AIDS. 2015;3(2):119-133.

21. Juhász A, Nagy C, Páldy A, Beale L. Development of a Deprivation Index and its relation to premature mortality due to diseases of the circulatory system in Hungary, 1998-2004. Soc Sci Med. 2010;70(9):1342-1349. https://doi.org/10.1016/j.socscimed.2010.01.024.

22. Slachtová $H$, Tomásková $H$, Splíchalová $A$, Polaufová $P$, Fejtková $P$. Czech socio-economic deprivation index and its correlation with mortality data. Int J Public Health 2009;54(4):267-273. https://doi.org/10.1007/s00038-008-7092-3.

23. Kozela M, Pająk A, Micek A, Besala A, Kubinova R, Malyutina S, et al. Impact of perceived control on all-cause and cardiovascular disease mortality in three urban populations of Central and Eastern Europe: the HAPIEE study. J Epidemiol Community Health. 2017;71(8):771-778. https://doi.org/10.1136/jech-2017-208992.

24. Tillmann T, Pikhart H, Peasey A, Kubinova R, Pajak A, Tamosiunas A, et al. Psychosocial and socioeconomic determinants of cardiovascular mortality in Eastern Europe: A multicentre prospective cohort study. PLoS Med. 2017;14(12):e1002459. https://doi.org/10.1371/journal.pmed.1002459.

25. Zatoński WA. Epidemiological analysis of health situation development in Europe and its causes until 1990. Ann Agric Environ Med. 2011;18(2):194-202.

26. Beblo M, Golinowska S, Laurer C, Pietka K, Sowa A. Poverty dynamics in Poland. Selected quantitative analyses. CASE Reports No. 54. Center for Social and Economic Research, Warsaw 2002.

27. Walsh D, Taulbut M, Hanlon P. The aftershock of deindustrialization - trends in mortality in Scotland and other parts of post-industrial Europe. Eur J Public Health 2010;20(1):58-64. https://doi.org/10.1093/eurpub/ckp063.

28. Halamska M. Transformacja wsi: 1989-2009. Zmienny rytm modernizacji. Studia Regionalne i Lokalne 2011;44(2):5-25.

29. Wojtyniak B, Moskalewicz J, Stokwiszewski J, Rabczenko D. Gender-specific mortality associated with alcohol consumption in Poland in transition. Addiction 2005;100(12):1779-1789. https://doi.org/10.1111/j.13600443.2005.01247.x.

30. Zatonski WA, McMichael AJ, Powles JW. Ecological study of reasons for sharp decline in mortality from ischaemic heart disease in Poland since 1991. BMJ. 1998;316(7137):1047-1051. https://doi.org/10.1136/bmj.316.7137.1047.

31. Bandosz P, O'Flaherty M, Drygas W, Rutkowski M, Koziarek J, Wyrzykowski B, et al. Decline in mortality from coronary heart disease in Poland after socioeconomic transformation: modelling study. BMJ. 2012;344:d8136. https://doi.org/10.1136/bmj.d8136.

32. European Commission: Regions in the European Union. Nomenclature of territorial units for statistics. NUTS 2006/EU27. https://ec.europa.eu/eurostat/web/products-manuals-and-guidelines/-/ks-ra-07-020Accessed 15 Nov 2020

Page $18 / 21$ 
33. The Council for Social Monitoring 2011. Social Diagnosis Report. http://www.diagnoza.com/index-en.html Accessed 15 Nov 2020

34. Morris JA, Gardner MJ. Calculating Confidence Intervals for Relative Risks (Odds Ratios) and Standardized Ratios and Rates. BMJ 1988; 296(6632):1313-1316. https://doi.org/10.1136/bmj.296.6632.1313.

35. Eurostat: Revision of the European Standard Population Report of Eurostat's task force. European Commission 2013 edition. https://ec.europa.eu/eurostat/web/products-manuals-and-guidelines/-/ks-ra-13-028 Accessed 15 Mar 2022

36. Hotchkiss JW, Davies CA, Dundas R, Hawkins N, Jhund PS, Scholes S, et al. Explaining trends in Scottish coronary heart disease mortality between 2000 and 2010 using IMPACTSEC model: retrospective analysis using routine data. BMJ. 2014;348:g1088. https://doi.org/10.1136/bmj.g1088.

37. Polak M, Genowska A, Szafraniec K, Fryc J, Jamiołkowski J, Pająk A. Area-based socio-economic inequalities in mortality from lung cancer and respiratory diseases. Int J Environ Res Public Health. 2019;16(10). pii: E1791. https://doi.org/10.3390/ijerph16101791.

38. Veronesi G, Ferrario MM, Kuulasmaa K, Bobak M, Chambless LE, Salomaa V, et al. Educational class inequalities in the incidence of coronary heart disease in Europe. Heart. 2016;102(12):958-965. https://doi.org/10.1136/heartjnl-2015308909.

39. Ricceri F, Sacerdote C, Giraudo MT, Fasanelli F, Lenzo G, Galli M, et al. The association between educational level and cardiovascular and cerebrovascular diseases within the EPICOR Study: new evidence for an old inequality problem. PLoS One. 2016;11(10):e0164130. https://doi.org/10.1371/journal.pone.0164130.

40. Bertuccio P, Alicandro G, Sebastiani G, Zengarini N, Costa G, La Vecchia C, et al. Mortality by occupation-based social class in Italy from 2012 to 2014. Int J Public Health. 2018;63(7):865-874. https://doi.org/10.1007/s00038-018-1149-8.

41. Kawachi I, Adler NE, Dow WH. Money, schooling, and health: mechanisms and causal evidence. Ann N Y Acad Sci. 2010;1186:56-68. https://doi.org/10.1111/j.1749-6632.2009.05340.x.

42. Meneton P, Kesse-Guyot E, Méjean C, Fezeu L, Galan P, Hercberg S, et al. Unemployment is associated with high cardiovascular event rate and increased all-cause mortality in middle-aged socially privileged individuals. Int Arch Occup Environ Health. 2015;88(6):707-716. https://doi.org/10.1007/s00420-014-0997-7.

43. Al-Turk B, Harris C, Nelson G, Smotherman C, Palacio C, House J. Poverty, a risk factor overlooked: a cross sectional cohort study comparing poverty rate and cardiovascular disease outcomes in the state of Florida. J Investig Med. 2018;66(3):693-695. https://doi.org/10.1136/jim-2017-000621.

44. Borrell C, Pons-Vigués M, Morrison J, Díez E. Factors and processes influencing health inequalities in urban areas. J Epidemiol Community Health. 2013;67(5):389-391. https://doi.org/10.1136/jech-2012-202014.

45. Zeger S, Liang K. Longitudinal data analysis for discrete and continuous outcomes. Biometrics. 1986;42(1):121-130.

46. Kondo N, Saito M, Hikichi H, Aida J, Ojima T, Kondo K, et al. Relative deprivation in income and mortality by leading causes among older Japanese men and women: AGES cohort study. J Epidemiol Community Health. 2015;69(7):680685. https://doi.org/10.1136/jech-2014-205103.

47. Niedhammer I, Bourgkard E, Chau N. Occupational and behavioural factors in the explanation of social inequalities in premature and total mortality: a 12.5-year follow-up in the Lorhandicap study. Eur J Epidemiol. 2011;26(1):1-12. https://doi.org/ 10.1007/s10654-010-9506-9.

48. Gillum RF, Mussolino ME. Education, poverty, and stroke incidence in whites and blacks: the NHANES I Epidemiologic Follow-up Study. J Clin Epidemiol. 2003;56(2):188-195. https://doi.org/10.1016/s0895-4356(02)00535-8.

49. Jackson CA, Mishra GD. Depression and risk of stroke in midaged women: a prospective longitudinal study. Stroke. 2013;44(6):1555-1560. https://doi.org/ 10.1161/STROKEAHA.113.001147.

50. Pujades-Rodriguez M, Timmis A, Stogiannis D, Rapsomaniki E, Denaxas S, Shah A, et al. Socioeconomic deprivation and the incidence of 12 cardiovascular diseases in 1.9 million women and men: implications for risk prediction and prevention. PLoS One. 2014;9(8):e104671. https://doi.org/10.1371/journal.pone.0104671. 
51. Ferrario MM, Veronesi G, Chambless LE, Tunstall-Pedoe H, Kuulasmaa K, Salomaa V, et al. The contribution of educational class in improving accuracy of cardiovascular risk prediction across European regions: The MORGAM Project Cohort Component. Heart. 2014;100(15):1179-1187. https://doi.org/10.1136/heartjnl-2013-304664.

52. Schaap MM, Kunst AE, Leinsalu M, Regidor E, Espelt A, Ekholm O, et al. Female ever-smoking, education, emancipation and economic development in 19 European countries. Soc Sci Med. 2009;68(7):1271-1278.

https://doi.org/10.1016/j.socscimed.2009.01.007.

53. Koopman C, Vaartjes I, van Dis I, Verschuren WM, Engelfriet P, Heintjes EM, et al. Explaining the decline in coronary heart disease mortality in the Netherlands between 1997 and 2007. PLoS One. 2016;11(12):e0166139.

https://doi.org/10.1371/journal.pone.0166139.

54. Lagström H, Halonen JI, Kawachi I, Stenholm S, Pentti J, Suominen S, et al. Neighborhood socioeconomic status and adherence to dietary recommendations among Finnish adults: A retrospective follow-up study. Health Place. 2019;55:4350. https://doi.org/10.1016/j.healthplace.2018.10.007.

55. Rethy LB, McCabe ME, Kershaw KN, Ahmad FS, Lagu T, Pool LR, Khan SS, Neighborhood Poverty and Incident Heart Failure: an Analysis of Electronic Health Records from 2005 to 2018. J Gen Intern Med. 2021;36(12):3719-3727. https://doi.org.10.1007/s11606-021-06785-7.

56. National Health Fund. Ischemic stroke of the brain. NHF, Warsaw 2019. [In Polish]

57. Strzelecki Z, Szymborski J. (red). Incidence and mortality from cardiovascular diseases and the demographic situation of Poland. Government Population Council, Warsaw 2015. [In Polish]

58. Marmot M. The Health Gap: The Challenge of an Unequal World: the argument. Int J Epidemiol. 2017;46(4):1312-1318. https://doi.org.10.1093/ije/dyx163.

59. Allik M, Leyland A, Travassos Ichihara MY, Dundas R. Creating small-area deprivation indices: a guide for stages and options. J Epidemiol Community Health. 2020;74(1):20-25. https://doi.org.10.1136/jech-2019-213255.

60. Krieger N, Chen JT, Waterman PD, Soobader MJ, Subramanian SV, Carson R. Geocoding and monitoring of US socioeconomic inequalities in mortality and cancer incidence: does the choice of area-based measure and geographic level matter?: the Public Health Disparities Geocoding Project. Am J Epidemiol. 2002;156(5):471-482. https://doi.org.10.1093/aje/kwf068.

61. Tawakol A, Osborne MT, Wang Y, et al. Stress-Associated Neurobiological Pathway Linking Socioeconomic Disparities to Cardiovascular Disease. J Am Coll Cardiol. 2019;73(25):3243-3255. https://doi.org.10.1016/j.jacc.2019.04.042.

62. Wojtyniak B, Jankowski K, Zdrojewski T, Opolski G. Regional differences in determining cardiovascular diseases as the cause of death in Poland: time for change. Kardiol Pol. 2012;70(7):695-701.

63. Mikkelsen L, Iburg KM, Adair T, Fürst T, Hegnauer M, von der Lippe E, et al. Assessing the quality of cause of death data in six high-income countries: Australia, Canada, Denmark, Germany, Japan and Switzerland. Int J Public Health. 2020;65(1):17-28. https://doi.org/10.1007/s00038-019-01325-x

\section{Figures}

\section{Figure 1}

Geographic variation of mean socioeconomic deprivation index (66 sub-regions of Poland, years 2010-2014) Map created using IBM SPSS Statistics for Windows ver. 20.0 - https://www.ibm.com/products/spss-statistics

\section{Supplementary Files}


This is a list of supplementary files associated with this preprint. Click to download.

- SupplementaryInformation.docx 